\title{
Third Party Fund Analysis Towards Bank Risk in the Banking Industry in Indonesia Stock Exchange
}

\author{
Shintia Mairani ${ }^{1 *}$, Dina Patrisia ${ }^{2}$ \\ 1, 2 Universitas Negeri Padang, Padang, Indonesia. \\ *Corresponding auhthor. Email: shintiamairani5@gmail.com
}

\begin{abstract}
This study aims to determine third party fund analysis towards bank risk in the banking industry in Indonesia stock exchange. An increase bank risk through assets and an increase in the total of third party funds that must be accepted banks as well as that development of course assets which tends to decline, therefore research is conducted on how third party funds affect bank risk in the banking industry. The subject or population in this study focuses on all banking industries that have been listed on the Indonesia Stock Exchange for the period 2014-2018. The data source uses secondary data. The sampling technique used purposive sampling. The number of samples in this study were 200 samples (40 companies with 5 years of research). The method of data analysis in this study used multiple linear regression with SPSS 16 as a measuring tool. Research results show the variable third party funds had no effect on bank risk using risk weighted assets. The variable third party fund has a negative and significant effect on bank risk using the loan loss provision. The variable third party fund has a negative and significant effect on bank risk using the $Z$ Score. The variable third party fund has no effect on bank risk using liquidity creation. The variable third party fund has a positive and significant effect on bank risk using stock returns.
\end{abstract}

Keywords: Third Party Funds and Bank Risk.

\section{INTRODUCTION}

Bank risk is the risk of all bank activities or the risk to assets faced during its operational activities [1]. This means that bank risk is a result that occurs from a company's operational activities that result in changes in company assets or liquidity. Bank risk can occur from systematic risk and unsystematic risk. Systematic risk is a result that occurs as a reaction to changes in market value that can impact bank operations, such as the current inflation rate. Unsystematic risk is a result that occurs result policies implemented by the company in its operational activities, such as decreased sales, so that this risk can be well anticipated.

In this study, the measurement of bank risk can be carried out through financial ratios that refer to previous research, namely by using the RWA analysis, loan loss provision (LLP) or CKPN, Z-score, liquidity creation (LC), and stock return (SRV) [2]. The phenomenon in this study took a sample of the five best banks according to Forbes America magazine published on March 5, 2019, namely BCA bank, Bank BTPN, Bank BNI, Bank
Mandiri, and Bank BRI. The use of these five banks is to see how the development of bank risk and liquidity funding in general in these companies. Development of bank risk as measured by BCA bank, Bank BTPN, Bank BNI, Bank Mandiri, and Bank BRI are:

There are two banks that have fluctuated development of risk weighted assets (RWA) towards an increase, namely Bank Negara Indonesia and Bank Mandiri. Development on an annual basis is moving towards an increase. The higher the risk weighted assets (RWA) of a bank, the greater the risk faced by the bank. The development of the loan loss provision (LLP) indicates that there are three banks that have decreased, namely Bank BCA, Bank Negara Indonesia and Bank Mandiri. Development based on annual averages is moving in a downward direction. The lower the loan loss provision (LLP), the higher the risk faced by the bank. The development of the z-score in the banks studied, there was one bank that had a decline, namely Bank Negara Indonesia and Bank Rakyat Indonesia. Development based on annual averages is moving in a downward direction. The lower the Z-score, the higher 
the risk that will be faced by the bank. The development of liquidty creation in the banks studied indicates that all banks have lower liquidty creation, namely Bank BCA, BNI, and Bank Mandiri. Development on an annual basis is moving in a downward direction. The lower the liquidty creation, the higher the risk faced by banks. The development of stock returns in the banks studied, there were no banks that had decreased stock returns. Based on the above phenomena, it can be concluded that there are several banks that have a high enough risk in managing their operations, namely BCA, Bank Mandiri and BNI.

Bank risk is affected by third party funds because third party funds are public funds managed by banks [2]. Management of public funds can be retrieved in a very short time, making them vulnerable in the event of an economic or financial crisis. The greater the third party funds managed by the bank, the higher the risks to be faced, including credit risk, financial risk and market risk. Third party funds are a source of bank funds originating from the general public, namely in the form of demand deposits, deposits and savings, meaning that the funds are returned to the public [3]. Third party funds are the largest funds that are the mainstay of banks, reaching $80 \%$ to $90 \%$ of the total funds managed by the bank. Third party funds can be used to encourage economic growth through lending to the public.

The financial innovation theory developed by Frame \& White (2004) explains that the placement of third party funds by customers is an alternative to digital money that generates non-interest income such as topping up credit, paying bills, and other [4]. So that the management of third party funds must be carried out effectively and efficiently. The development of third party funds based on deposits is the development of deposits from the five banks studied, there were four banks that decreased in 2018, namely BCA, Bank BTPN, Bank BNI, and Bank BRI. This decrease explains that bank management is still careful in managing deposits because a decrease in time deposits can interfere with bank funding sources in generating profits through credit. So the potential risk of a bank will be even higher because the bank cannot distribute credit to the public if one of the sources of third party funds has decreased.

The phenomenon that occurs is that there is an increase in bank risk through assets and an increase in the amount of third party funds that must be received by banks as well as the development of assets that tends to decline, so research must be carried out on the impact of these third party funds on bank risk. Explanation of the above background regarding the risk of banks and third party funds, the authors are interested in conducting research on this issue by providing a title "Analysis of Third Party Funds Against Bank Risk in the Banking
Industry Listed on the Indonesia Stock Exchange for the 2014-2018 Period".

\section{THEORETICAL BASIS}

\subsection{Prospect Theory}

Prospect theory predicts an increase in risk-taking behavior when there is a low chance of risk occurring [5]. If the probability of risk occurring decreases it will have a higher effect on long-term risk for financial services such as banks. As a result, bank income decreases which in turn can lead to bigger risks such as a decline in financial performance and market performance.

\subsection{Financial Innovation Theory}

The theory of financial innovation developed by Frame \& White (2004) explains that the placement of third party funds by customers is an alternative to digital money that generates non-interest income such as topping up credit, paying bills, and others [4]. So that the management of third party funds must be carried out effectively and efficiently.

\subsection{Bank Risk}

Bank risk is the risk of all bank activities or the risk to assets faced during its operational activities [1]. This means that bank risk is a result of operational activities within the company which have an impact on changes in the company's assets or liquidity. If it is not properly analyzed, bank risk will result in changes to the economy and can drag the country into the vortex of a national or global economic downturn. For this reason, the government and company management must supervise all operational activities in order to minimize risks.In this study, the measurement of bank risk can be carried out through financial ratios which refer to Khan's (2017) research, namely :

\subsubsection{Risk Weighted Assets}

Total assets are proxied by bank risk because it is a measure of the main credit risk based on the agreement [2]. Risk weighted assets are calculated based on the cost of capital so that they are highly relevant to the quality of assets with risk. According to Khan (2017) the formulas that can be used are:

$$
\begin{aligned}
& R W A=\frac{\text { Risk Wighted Asset }}{\text { Total Assets }} \\
& R W A=\text { Total Loans }+ \text { Securities }
\end{aligned}
$$

\subsubsection{Loan Loss Provision}

Loan loss provision (LLP) is a loan loss maintained by a bank if there is a possibility of bad credit so that it must be reserved where it shows that the bank has risky 
assets [2]. This measurement is carried out using the standard deviation of the loan loss risk provisions against the total loan that reflects the previous year's investment decision. Loan loss provisions (LLP) may reflect the aggressiveness of previous bank lending decisions. According to Khan (2017) the formula that can be used is:

$$
L L P=\frac{\text { Beban (Pendapatan) CKPN }}{\text { Total Kredit yang diberikan }}
$$

\subsubsection{Z-score}

$\mathrm{Z}$-score is a bank risk measurement carried out as a whole by means of return of assets plus the ratio of capital to assets divided by the standard deviation of return on assets [2]. The Z-score measurement is widely used to measure bank risk from the bankruptcy distance. According to Khan (2017) the formula that can be used is:

$$
\begin{aligned}
& Z-\text { Score }=\frac{\log (\text { ROA }+(\text { Modal Aset })}{\text { Standar Deviasi ROA }} \\
& R O A=\frac{\text { Laba bersih }}{\text { Total Aset }}
\end{aligned}
$$

\subsubsection{Liquidity Creation}

Liquidity creation is created through commitments that are outside the balance sheet to supply liquidity to borrowers and insured depositors [6]. Liquidity creation can enjoy synergy when depositors can fund loan commitments, so it is effective in protecting the inherent liquidity risk with a clear effect. According to Cornett (2011) the formula that can be used is:

$$
L C=\frac{\Delta \text { Liquid Asset }}{\text { Total Aset-l }}
$$

$\Delta$ Liquid Asset $=$ Liquid Assett - Liquid Assett-1 Total Asett-1 = Total Assets for the Previous Period

\subsubsection{Stock Return}

Stock return (SRV) is a market based assessment of bank risk as a whole which can be measured by the standard deviation of returns on bank shares [2]. The volatility of the quarterly return on shares for the bank is calculated from the daily returns on the bank's shares for each quarter. The use of standard deviation on stock returns can promote overall bank risk. According to Khan (2017) the formula that can be used is:

$\mathrm{SRV}=$ Standard deviation of daily stock returns in period $t$

$$
\text { Return Share }=\frac{\text { Harga Sahamt }- \text { Harga Sahamt }-1}{\text { Harga Sahamt }-1} x 100
$$

\subsection{Third Party Funds}

Third party funds are a source of funds originating from the wider community, meaning that customers keep their funds in a bank where the funds are used for lending, sources of funds from the public are in the form of demand deposits, savings and time deposits [7]. This source of funds sourced from the public is very important for bank operations and is a measure of the success of a bank. Third party funds are obtained from deposits so that customers save in a bank where the funds stored can be used for lending so that banks benefit from the difference between loan interest and deposit interest. Third party funds in this study only focus on deposits because they have the lowest development compared to savings and current accounts. In this study, the measurement of third party funds refers to Khan's (2017) research, namely:

$$
D P K=\frac{\text { Total Deposito }}{\text { Total Aset }}
$$

\subsection{Conceptual Framework}

This conceptual framework is intended as a concept to explain, express and determine perceptions in the relationship of variables to be studied based on constraints and problem formulations. The linkages and relationships between the variables studied are described based on the theoretical study above. Based on the description that has been explained, it can be described into a conceptual research framework, so that this research is more focused later as shown below:



Figure 1. Conceptual Framework

\section{RESEARCH METHODS}

This type of research is classified as a causative research, in other words the purpose of this research is to be able to state that the independent variable is the cause of the dependent variable so that it can find the influence between these variables. Causative research is a study that tests whether one variable causes another variable to change or not [8]. In other words, the purpose of this study is to be able to state that the independent variable is the cause of the dependent variable so that it can find a influence between these 
variables. This study explains relationship between the independent variable, namely third party funds, to the dependent variable, namely bank risk. This study analyzes the extent of the influence of third party funds on the dependent variable, namely bank risk in the banking industry in Indonesia Stock Exchange. According to experts, where the population in a study is an area of generalization consisting of objects or subjects, meaning that this object or subject has certain qualities and characteristics determined by a researcher to be studied, researched and then conclusions drawn [9]. Thus, population in this study regarding third party funds on bank risk can be taken, namely all banks listed on the Indonesia Stock Exchange for the 2014-2018 period with which report complete data. So that the population in this study were 43 companies. According to experts, this sample is a part of the research population which is related to the number and characteristics of the population [9]. Where this research uses certain criteria or often referred to as purposive sampling technique. Purposive sampling technique a technique in which the determination of the sample is based on certain criteria determined by the researcher [9]. The sampling criteria were all banking industries that reported complete data per year and were listed on the Indonesia Stock Exchange until 2019 and banking companies that report complete annual reports from 2014 to 2018. Based on these criteria, the number of samples studied was 40 companies in the 2014 to 2018 period. Thus the number of samples in this study were 200 samples (40 companies x 5 years of research).

\section{RESULTS AND DISCUSSION}

The results of the descriptive test in this study are:

Table 1. Research Descriptive Test Results

\begin{tabular}{|c|c|c|c|c|c|}
\hline \multicolumn{6}{|c|}{ DescriptiveStatistics } \\
\hline & $\mathbf{N}$ & Minimum & Maximum & Mean & Std. Deviation \\
\hline RiskWeightedAssets & 200 & 0.15 & 0.95 & 0.7276 & 0.10087 \\
\hline LoanLossProvision & 200 & 0.00 & 0.11 & 0.0213 & 0.01609 \\
\hline Z Score & 200 & -852 & 9.98 & 0.0275 & 2.41964 \\
\hline LiquidityCreation & 200 & -7.70 & 26.60 & 0.2563 & 2,09543 \\
\hline StockReturn & 200 & 0.00 & 11.87 & 2.9639 & 2.20623 \\
\hline Third-party funds & 200 & 0.00 & 0.88 & 0.4941 & 0.19157 \\
\hline Debt & 200 & 0.08 & 0.95 & 0.8042 & 0.16544 \\
\hline Capital & 200 & 0.03 & 0.80 & 0.1517 & 0.06688 \\
\hline ROA & 200 & -11.23 & 8.02 & 0.8450 & 1.95120 \\
\hline Valid N (listwise) & 200 & & & & \\
\hline
\end{tabular}

Source: Self-processed secondary data, 2020

Based on Table 1, the lowest risk weighted assets (RWA) value is 0.15 times. This means that the lowest amount of credit extended is 0.15 times the company's total assets, which occurred at Bank Himpunan Saudara 1906 (SDRA) in 2014. The highest value of risk weighted assets (RWA) is 0.95 times. This means that the highest amount of credit extended is 0.95 times the company's total assets, which occurred at Bank Permata (BNLI) in 2014. The average value of risk weighted assets (RWA) is 0.72 times. This means that the average amount of credit extended to the banking industry is 0.72 times the company's total assets. The standard deviation of risk weighted assets (RWA) is 0.10 times.

The lowest value of the loan loss provision (LLP) is 0 times. This means that there are companies that do not reserve the value of losses in case of bad credit on loans, namely Bank Agris / Bank Finconesia (AGRS) in 2014 and Bank Himpunan Saudara 1906 (SDRA) in 2014. The highest value of loan loss provision (LLP) is 0.11 times. This means that the maximum allowance for impairment losses is 0.11 times the total credit provided by the company, which occurred at Panin Syariah Bank (PNBS) in 2017. The average value of loan loss provision (LLP) is 0.02 times. This means that the average impairment loss to the banking industry is 0.02 times the total credit extended.

The lowest value of the $\mathrm{Z}$ Score is -8.52 times. This means that the bank risk based on the bankruptcy distance is at the lowest of -8.52 times the rate of return on assets and bank capital that occurred at Bank Nationalnobu (NOBU) in 2017. The highest value of the $\mathrm{Z}$ Score is 9.98 times. This means that the bank risk based on the bankruptcy distance is 9.98 times the rate of return on bank assets and capital, which occurred at Bank Central Asia (BBCA) in 2018. The average Z Score is 0.02 times. This means that the average bank risk based on the bankruptcy distance is 0.02 times the rate of return on bank assets and capital. The standard deviation of the $\mathrm{Z}$ Score is 2.41 times.

The lowest value of liquidity creation (LC) is -7.70 times. This means that the bank's ability to manage bank risk on its liquid assets is at the lowest of -7.70 times 
that of the 1906 Bank Association (SDRA) in 2014. The highest value of liquidity creation (LC) is 26.60 times. This means that the bank's ability to manage bank risk on its liquid assets is 26.60 times, which happened to Panin Syariah Bank (PNBS) in 2015. The average value of liquidity creation (LC) is 0.25 times. This means that the average bank's ability to manage bank risk on liquid assets is 0.25 times. The standard deviation of liquidity creation (LC) is 2.09 times.

The lowest value of stock return (SRV) is 0 times. This means that the measurement of bank risk is based on the lowest stock return of 0 times that occurred at Bank Artos Indonesia (ARTO) in 2014 and 2015, Bank MNC International (BABP) in 2014, Bank Harda Internasional (BBHI) in 2014, Bank Yudha Bhakti (BBYB). in 2014, Bank Ganesha (BGTG) in 2014 and 2015, Bank BRI syariah (BRIS) from 2014 to 2017, and Sharia National Pension Savings Bank (BTPS) from 2014 to 2017. The highest value of stock return (SRV) was 11.87 times. This means that the measurement of bank risk is based on the highest return on shares of 11.87 times, which occurred at Bank Harda Internasional (BBHI) in 2016. The average stock return (SRV) is 2.96 times. This means that the average bank risk measurement based on the stock return is 2.96 times. The standard deviation of stock return (SRV) is 2.20 times.

The lowest value of third party funds (DPK) is 0.002 times. This means that the lowest total third party funds amounted to 0.002 times the company's total assets that occurred at Bank Mestika Dharma (BBMD) in 2014. The highest value of third party funds (DPK) was 0.88 times. This means that the highest total third party funds is 0.88 times of its total assets, which happened to Bank Victoria International (BVIC) in 2017. The average value of third party funds (TPF) is 0.49 times. This means that the average total third party funds is 0.49 times the total assets. The standard deviation of third party funds (DPK) is 0.19 times.

The lowest value of debt is 0.08 times. This means that the lowest total debt is 0.08 times the company's total assets that occurred in Panin Syariah Bank (PNBS) in 2017. The highest value of debt is 0.95 times. This means that the highest total debt is 0.95 times its total assets, which occurred at the Banten Regional Development Bank (BEKS) in 2015. The average debt value is 0.80 times. This means that the average total debt is 0.80 times the total assets. The standard deviation of debt is 0.16 times.

The lowest value for capital is 0.03 times. This means that the lowest total capital is 0.03 times the company's total assets that occurred in Panin Syariah Bank (PNBS) in 2017. The highest value of capital is 0.80 times. This means that the highest total capital is 0.80 times of its total assets, which happened to Bank Rakyat Indonesia Agro Niaga (AGRO) in 2014. The average value of capital is 0.15 times. This means that the average total capital is 0.15 times the total assets. The standard deviation of capital is 0.06 times.

The lowest value of ROA is $-11.23 \%$. This means that the lowest net profit is $-11.23 \%$ of the company's total assets that occurred in Panin Syariah Bank (PNBS) in 2017. The highest value of ROA is $8.02 \%$. This means that the highest total profit is $8.02 \%$ of total assets, which occurred in the Sharia National Pension Savings Bank (BTPS) in 2018. The average ROA value is $0.84 \%$. This means that the average total net income is $0.84 \%$ of total assets. The standard deviation of ROA is $1.95 \%$.

Multiple linear regression test functions to see changes in the dependent variable that are influenced by the independent variable. Multiple linear regression functions to see changes and relationships formed between an variable independent and the variable dependent. Linear regression multiple tests fall into the category of parametric statistics.

\subsection{Model 1 (No Control Variable)}

The results of multiple linear regression tests without control variables are:

Table 2. Multiple Linear Regression Test Results without Control Variables

\begin{tabular}{|c|c|c|c|c|c|c|c|c|c|c|c|c|c|c|c|}
\hline & \multicolumn{3}{|c|}{ Model 1} & \multicolumn{3}{|c|}{ Model 2} & \multicolumn{3}{|c|}{ Model 3} & \multicolumn{3}{|c|}{ Model 4} & \multicolumn{3}{|c|}{ Model 5} \\
\hline & B & $t$ & sig & B & $\mathbf{T}$ & sig & B & $t$ & sig & B & $\mathbf{T}$ & sig & B & $\mathbf{t}$ & sig \\
\hline Constant & 0.710 & 35,912 & 0,000 & 0.029 & 9,369 & 0,000 & 1,525 & 13,665 & 0,000 & $-0,930$ & $\mid-8,367$ & 0,000 & 0.206 & 4,144 & 0,000 \\
\hline $\begin{array}{l}\text { Third party } \\
\text { funds }\end{array}$ & 0.035 & 0.936 & 0.351 & -0.016 & $-2,705$ & 0.007 & $-1,483$ & $-7,040$ & 0,000 & 0.364 & 1,734 & 0.084 & 0.389 & 4,136 & 0,000 \\
\hline
\end{tabular}

Source: Self-processed secondary data, 2020

The results of multiple linear regression tests without control variables can be formed as follows: The regression equation in model 1 is $\mathrm{RWA}=0.710+$ $0.035 \mathrm{DPK}+\mathrm{e}$. The constant value is 0.710 with a positive sign, if third party funds are zero then risk weighted assets (RWA) will increase by 0.710 or $71 \%$. The regression coefficient value for third party funds is
0.035 with a positive sign, each increase in third party funds will increase risk weighted assets (RWA) by 0.035 or $3.5 \%$. The regression equation in model 2 is LLP $=0.029-0.016 \mathrm{DPK}+\mathrm{e}$. The constant value is 0.029 with a positive sign, if third party funds are zero, the loan loss provision (LLP) will increase by 0.029 or $2.9 \%$. The regression coefficient value for third party 
funds is 0.016 , which is negative, each increase in the variable third party funds by $1 \%$ will reduce the allowance for loan losses (LLP) by 0.016 or $1.6 \%$. The regression equation in model 3 is $\mathrm{Z}$-Score $=1.525-$ 1.483DPK + e. The constant value is 1.525 with a positive sign, if the third party funds are zero, the ZScore will increase by 1.525 or $152.5 \%$. The regression coefficient value for third party funds is -1.483 with a negative sign, every decrease Z-Score by 1.483 or $148.3 \%$. The regression equation in model 4 is $\mathrm{LC}=-$ $0.930+0.364 \mathrm{DPK}+\mathrm{e}$. The constant value is 0.930 with a negative sign, if third party funds are zero then the liquidty creation (LC) will decrease by 0.930 or $9.30 \%$. The regression coefficient value of third party funds is
0.364 with a positive sign, every $1 \%$ increase in third party funds will increase liquidty creation (LC) by 0.364 or $36.4 \%$. The regression equation in model 5 is $\mathrm{SRV}=$ $0.206+0.389 \mathrm{DPK}+\mathrm{e}$. The constant value is 0.206 with a positive sign, if third party funds are zero, the stock return (SRV) will increase by 0.206 or $20.6 \%$. The regression coefficient value of third party funds is 0.389 with a positive sign, each increase in the third party funds variable by $1 \%$ will increase the stock return (SRV) by 0.389 or $38.9 \%$.

\subsection{Using Control Variables}

The results of multiple linear regression tests with control variables are:

Table 3. Multiple Linear Regression Test Results with Control Variables

\begin{tabular}{|l|c|c|c|c|c|c|c|c|c|c|c|c|c|c|c|}
\hline & \multicolumn{3}{|c|}{ Model 6 } & \multicolumn{3}{|c|}{ Model 7 } & \multicolumn{3}{c|}{ Model 8 } & \multicolumn{2}{c|}{ Model 9 } & & Model 10 & \\
\hline & B & $\mathrm{t}$ & $\mathrm{sig}$ & $\mathrm{B}$ & $\mathrm{t}$ & $\mathrm{sig}$ & $\mathrm{B}$ & $\mathrm{t}$ & $\mathrm{sig}$ & $\mathrm{B}$ & $\mathrm{t}$ & $\mathrm{sig}$ & $\mathrm{B}$ & $\mathrm{t}$ & $\mathrm{sig}$ \\
\hline Constant & 0.458 & 9,967 & 0,000 & 0.061 & 8,277 & 0,000 & 0.741 & 2,740 & 0.007 & -0.305 & $-1,114$ & 0.267 & $-0,110$ & $-0,897$ & 0.371 \\
\hline $\begin{array}{l}\text { Third-party } \\
\text { funds }\end{array}$ & 0.061 & 1,647 & 0.101 & -0.029 & $-4,91$ & 0,000 & $-1,166$ & $-5,372$ & 0,000 & 0.032 & 0.144 & 0.886 & 0.342 & 3,479 & 0.001 \\
\hline Debt & 0.272 & 6,683 & 0,000 & -0.026 & $-3,936$ & 0,000 & 0.310 & 1,296 & 0.197 & $-0,637$ & $-2,636$ & 0.009 & 0.275 & 2,542 & 0.012 \\
\hline Capital & 0.136 & 1,326 & 0.186 & -0.015 & $-0,93$ & 0.353 & 2,154 & 3,578 & 0,000 & 0.788 & 1,295 & 0.197 & 0.921 & 3,380 & 0.001 \\
\hline ROA & 0.0001 & 0.031 & 0.975 & -0.003 & $-4,76$ & 0,000 & 0.061 & 2,772 & 0.006 & 0.081 & $-3,648$ & 0,000 & -0.025 & $-2,563$ & 0.011 \\
\hline
\end{tabular}

Source: Self-processed secondary data, 2020

The results of multiple linear regression tests without control variables can be formed as follows: The regression equation in model 6 is RWA = $0.458+0.061 \mathrm{DPK}+0.272 \mathrm{UT}+0.136 \mathrm{MD}+0.0001 \mathrm{ROA}+$ e. The constant value is 0.458 with a positive sign, if third party funds, debt, capital, and ROA are zero, risk weighted assets (RWA) will increase by 0.458 or $45.8 \%$. The regression coefficient value of third party funds is 0.061 with a positive sign, each increase in third party funds will increase risk weighted assets (RWA) by 0.061 or $6.1 \%$. This result is the same without using control variables. The value of the debt regression coefficient is 0.272 with a positive sign, each increase in debt will increase risk weighted assets (RWA) by 0.272 or $27.2 \%$. The capital regression coefficient value is 0.136 with a positive sign, each capital increase will increase risk weighted assets (RWA) by 0.136 or $13.6 \%$. The ROA regression coefficient value is 0.0001 with a positive sign, every $1 \%$ increase in ROA will increase risk weighted assets (RWA) by 0.0001 or $0.01 \%$.

The regression equation in model 7 is LLP $=0.061$ 0.029DPK-0.026UT-0.015MD-0.003 ROA+e. The constant value is 0.061 with a positive sign, if third party funds, debt, equity, and ROA are zero, the loan loss provision (LLP) will increase by 0.061 or $6.1 \%$. The regression coefficient value for third party funds is
0.029 with a negative sign, every reduce loan loss provision (LLP) by 0.029 or $2.9 \%$. This result is the same without using control variables. The debt regression coefficient value is 0.026 with a negative sign, every $1 \%$ increase in debt will reduce the loan loss provision (LLP) by 0.026 or $2.6 \%$. The capital regression coefficient value is 0.015 with a negative sign, every $1 \%$ increase in capital will decrease the loan loss provision (LLP) by 0.015 or $1.5 \%$.

The regression equation in model 8 is Z-Score = 0.741-1.166DPK+0.310UT + 2.154MD + 0.061ROA + e. The constant value is 0.741 with a positive sign, if third party funds, debt, equity, and ROA are zero, the ZScore will increase by 0.741 or $74.1 \%$. The regression coefficient value of third party funds is 1.166 with a negative sign, every decrease Z-Score by 1.166 or $116.6 \%$. This result is the same without using control variables. The value of the debt regression coefficient is 0.310 with a positive sign, every $1 \%$ increase in debt will increase the Z-Score by 0.310 or $31 \%$. The capital regression coefficient value is 2.154 with a positive sign, every $1 \%$ increase in capital will increase the ZScore by 2.154 or $215.4 \%$.

The regression equation in model 9 is $\mathrm{Z}$-Score = 0,305+0,032DPK-0,637UT+0,788 MD-0,081ROA + e. The constant value is 0.305 with a negative sign, if third 
party funds, debt, equity, and ROA are zero, the liquidty creation (LC) will decrease by 0.305 or $30.5 \%$. The regression coefficient value of third party funds is 0.032 with a positive sign, every $1 \%$ increase in third party funds will increase liquidty creation (LC) by 0.032 or $3.2 \%$. This result is the same without using control variables. The value of the debt regression coefficient is 0.637 with a negative sign, each $1 \%$ increase in debt will reduce liquidty creation (LC) by 0.637 or $63.7 \%$. The capital regression coefficient value is 0.788 with a positive sign, every $1 \%$ increase in capital will increase liquidty creation (LC) by 0.788 or $78.8 \%$.

The regression equation in model 10 is SRV = 0,110+0,342DPK+0,275UT+0,921MD $-0,025 \mathrm{ROA}+\mathrm{e}$. The constant value is 0.110 with a negative sign, if third party funds, debt, equity, and ROA are zero, the stock return (SRV) will decrease by 0.110 or $11 \%$. The regression coefficient value of third party funds is 0.342 with a positive sign, every increase stock return (SRV) by 0.342 or $34.2 \%$. This result is the same without using control variables. The value of the debt regression coefficient is 0.275 with a positive sign, every $1 \%$ increase in debt will increase the stock return (SRV) by 0.275 or $27.5 \%$. The capital regression coefficient value is 0.921 with a positive sign, every $1 \%$ increase in capital will increase the stock return by 0.921 or $92.1 \%$.

\section{HYPOTHESIS TEST RESULTS}

Hypothesis testing $\mathrm{t}$ is done partially because we want to know how the influence of the variable dependent and the variable independent in a study, meaning that if the value of $t$ count $>t$ table and significance $<0.05$, it can be concluded that a partially significant effect between the variable independent and the dependent [10]. $\mathrm{T}$ table in $\mathrm{df}=200-1=199$ and a significance of 0.05 of 1.971 . The results from the partial $\mathrm{t}$ examine in this study could make vesible in tables 2 and 3 with the following information:

\subsection{No Control Variable}

Model 1 explains that third party funds have a regression coefficient value of 0.035 with a $t$ count $<\mathrm{t}$ table $(0.936<1.971)$, and a significance $>$ alpha $(0.351$ $>0.05$ ) meaning that $\mathrm{Ha}$ is rejected and $\mathrm{HO}$ is accepted. The conclusion is to explain that this third party fund has a positive and insignificant effect on risk weighted assets (RWA). Model 2 explains that this third party fund has a regression coefficient value of -0.016 with a total value of $\mathrm{t}$ count $>\mathrm{t}$ table $(2.705>1.971)$ and $\mathrm{a}$ significance value of $<$ alpha $(0.007<0.05)$, meaning that the research hypothesis is that $\mathrm{Ha}$ is accepted and $\mathrm{HO}$ is rejected. The conclusion is to explain that the variable third party funds has a negative and significant effect on the Allowance for Loan Losses (LLP). Model 3 explains that third party funds have a regression coefficient value of -1.483 with a value of $t$ count $>t$ table $(7.040>1.971)$ and has a significance value < alpha $(0.000<0.05)$ meaning that the research hypothesis is that $\mathrm{Ha}$ is accepted and $\mathrm{HO}$ is rejected. The conclusion is to explain that this third party fund has a negative and significant effect on the $\mathrm{Z}$ Score variable. Model 4 explains that this variable, namely third party funds, has a regression coefficient value of 0.364 with a value of $\mathrm{t}$ count $<\mathrm{t}$ table $(1.734<1.971)$ and has a significance value $>$ alpha $(0.084>0.05)$ so that the results for the research hypothesis are Ha rejected. and HO is accepted. This conclusion explains that the variable third party funds has a positive and insignificant effect on liquidity creation (LC). Model 5 explains that this variable, namely third party funds, has a regression coefficient value of 0.389 with a value of $t$ count $>\mathrm{t}$ table $(4,136>1,971)$ and has a significance value $<$ alpha $(0,000<0.05)$, meaning that the results for the research hypothesis are that Ha accepted and H0 rejected.

\subsection{With Control Variables}

Model 6 explains that this variable, namely third party funds, has a regression coefficient value of 0.061 with a value of $\mathrm{t}<\mathrm{t}$ table $(1.647<1.971)$, and has a significance value $>$ alpha $(0.101>0.05)$, then $\mathrm{Ha}$ is rejected and $\mathrm{HO}$ is accepted. The conclusion is to explain that the variables of third party funds have a positive and insignificant effect on risk weighted assets (RWA) using control variables. Conclusion using control variables does not provide significant result, or the same as without using control variables.

Model 7 explains that this variable, namely third party funds, has a regression coefficient of -0.029 with a value of $t$ count $>t$ table $(4.917>1.971)$ and has a significance value $<$ alpha $(0.000<0.05)$, then $\mathrm{Ha}$ is accepted and $\mathrm{HO}$ is rejected. The conclusion is to explain that the variable third party funds has a negative and significant effect on the loan loss provision (LLP) by using the control variable. Conclusion using control variables gives significant results, but still the same without using control variables. The control variables used, namely debt, capital, and ROA, are able to control the relationship of third party funds to the loan loss provision.

Model 8 explains that this variable, namely third party funds, has a regression coefficient value of $-1,166$ with a value of $t$ count $>t$ table $(5,372>1,971)$ and has a significance value $<$ alpha $(0,000<0.05)$, then the hypothesis is concluded, namely $\mathrm{Ha}$ accepted and $\mathrm{H} 0$ rejected. The conclusion is to explain that the variable of third party funds has a negative and significant effect on the Z Score by using the control variable. Conclusion using control variables gives significant results, but still the same without using control variables. The control variables used, namely debt, capital, and ROA, are able to control the relationship of third party funds to the $\mathrm{Z}$ Score. 
Model 9 explains that this variable, namely third party funds, has a regression coefficient value of 0.032 with a value of $t$ count $<\mathrm{t}$ table $(0.144<1.971)$ and has a significance value $>$ alpha $(0.886>0.05)$, so that $\mathrm{Ha}$ is rejected and $\mathrm{H} 0$ is accepted. . The conclusion explains that the variable of third party funds has a positive and insignificant effect on liquidity creation (LC) using the control variable. The conclusion that using control variables gives insignificant results, it is the same as without using control variables. The control variables used, namely debt, capital, and ROA, are unable to control the relationship of third party funds to liquidty creation (LC).

Model 10 explains that this variable, namely third party funds, has a regression coefficient value of 0.342 with a value of $t$ count $>t$ table $(3.479>1.971)$ and has a significance value $<$ alpha $(0.001<0.05)$, so it can be concluded that the results of the hypothesis research, namely $\mathrm{Ha}$ accepted and $\mathrm{H} 0$ rejected. The conclusion explains that the variable of third party funds has a positive and significant effect on stock returns (SRV) using control variables. Conclusion using control variables gives significant results, but still the same without using control variables. The control variables used, namely debt, capital, and ROA, are able to control the relationship of third party funds to stock return (SRV).

\section{DISCUSSION}

\subsection{The Effect of Third Party Funds on Bank Risk Using Risk Weighted Asset (RWA)}

The hypothesis in this study explains that third party funds have a positive and significant effect on the risk of using banks risk weighted assets (RWA). The results of hypothesis testing without using control variables or using control variables concluded that third party funds had no effect on bank risk using risk weighted assets (RWA) because the significance values were 0.351 > 0.05 and $0.101>0.05$. The meaning is that third party funds are not at risk to the bank based on the credit given. Risk based bank risk weighted assets (RWA) is a risk measurement based on credit provided by the company. Most of the use of third party funds is to finance credit to customers. The rules regarding the management of third party funds on loans are carried out strictly, thus allowing for a small risk of bank loss. This results in the amount of third party funds received will not have an impact on bank risk using risk weighted assets (RWA).

The results of research on third party funds on bank risk are also supported by previous research conducted by Pangestuti (2018) which concluded that the variable of third party funds has no effect on the risk of the Bank using risk weighted assets (RWA) [11]. However, this study does not support research conducted by Khan (2017) which concluded that the variable of third party funds has a significant effect in bank risk using risk weighted assets (RWA). The results of this study are not supportive prospect theory which explains an increase in risk-taking behavior, the risk will tend to decrease. The theory explains that the higher the risk taking, the lower it will be in forming opportunities for losses from this risk. The banking industry is an industry whose main activities involve credit risk, however, it is regulated by law. With the tight supervision by Bank Indonesia and Financial Services Authority on credit risk management, the increase or decrease at from the inside of amount of third party funds in the bank will not affect level of bank credit risk.

\subsection{The Effect of Third Party Funds on Bank Risk Using Loan Loss Provision (LLP)}

The hypothesis in this study explains that third party funds have a positive and significant effect on the risk of using banksloan loss provision (LLP). The results of hypothesis testing without using control variables or using control variables conclude that the variable of third party funds had a negative and significant effect to bank risk loan loss provision (LLP) because the significance value is $0.007<0.05$ and $0.000<0.05$. This means that each addition of third party funds will reduce bank risk based on asset reserves in the credit provided. Risk based bank loan loss provision (LLP) is a risk measurement based on asset reserves on loans. The provision for impairment for losses in case of bad credit will increase bank spending based on third party funds. The greater the management of third party funds in a bank, the smaller the risk of the bank based on the value of its asset reserves for the possibility of bad credit. The increasing amount of third party funds will encourage sufficient funds to allow for impairment losses on the loan.

Results of this study are supported by previous research conducted by Pangestuti (2018) concludes that third party funds have a significant effect on bank risk [11]. However, this study does not support the research conducted by Khan (2017) which concluded that third party funds have no effect on bank risk using the loan loss provision (LLP). This means that the more deposits received by bank, the bank must take a higher risk to get compensation to be given to customers and seek profit based on loan interest rates. The higher the management of third party funds, the lower the risk of the bank based on the provision for impairment losses or loan loss provision (LLP).

\subsection{Effect of Third Party Funds on Bank Risk Using Z Score}

The hypothesis in this study explains that third party funds have a positive and significant effect on the risk of using banks Z Score. The results of hypothesis testing without using control variables or using control variables concluded that the variable of third party funds 
namely has a negative and significant effect the bank risk $\mathrm{Z}$ Score because the significance value is 0.000 $<0.05$ and $0.000<0.05$. This means that any increase in third party funds will reduce bank risk based on bankruptcy distance through the return of assets and capital. Risk based bank Z Score is a risk measurement from the bankruptcy distance based on the rate of return on assets and capital. The existence of a high rate of return on assets will keep the bank from the possible risk of loss from the level of deviations in profit and assets. The higher the profit obtained, the further the bank will be kept away from the possibility of the risk of financial loss which is marked by a decrease in the deviation of return on bank assets. However, the management of third party funds can cause quite a large burden, such as interest expense on deposits, which can reduce company profits. The result will accelerate the risk of bank bankruptcy. The greater the bank's third party funds, the lower the $\mathrm{Z}$ score will be due to a decrease in profit so that the level of deviation in asset returns is greater.

The results of this study are supported by previous research conducted by Khan (2017), Thai Ha (2018), and Dahir (2018) who concluded that third party funds have a significant effect on bank risk. The existence of support from previous research strengthens the theory of risk bankruptcy distance. Results in this research on bank risk are also related to the liquidity risk theory developed by Diamond and Dybvig (1983) explaining that liquidity creation can be done on the balance sheet liability side which allows depositors to share risks with banks because it can prevent uncertainty over their consumption The bank provides the opportunity for the actors of third party funds to invest simply with a predetermined return and the bank also ensures that the depositor has the right to withdraw whenever needed. Based on the concept of bank profit, the management of third party funds that is too large will tend to reduce the value of return ( $\mathrm{Z}$ Score) so that the possibility of the risk of bankruptcy becomes higher.

\subsection{The Effect of Third Party Funds on Bank Risk Using Liquidity Creation (LC)}

The hypothesis in this study explains that third party funds have a positive and significant effect on the risk of using banks liquidity creation (LC). The results of hypothesis testing without using control variables or using control variables concluded that third party funds had no effect on the risk of using the bank liquidity creation (LC) because the significance value is $0.084>$ 0.05 and $0.886>0.05$. This means that the increase in third party funds does not have an impact on bank risk based on the management of its liquid assets. Risk based bank liquidity creation (LC) is a risk measurement based on the ability to manage its liquid assets. The main function of a bank is an intermediary institution (intermediary) between deposit customers and credit customers. Customer deposits are a debt to the bank because they are only a deposit of money where the bank has to pay interest on these deposits. Loans provided are the most risky liquid assets for banks because they provide income in the form of credit interest income. All of these activities are closely monitored by Bank Indonesia and refer to Law Number 10 of 1998 concerning Banking. The management of liquid assets is also supervised by bank management so that the possibility of liquidity risk will be smaller so that the management of third party funds does not affect bank risk based on liquidity creation (LC).

The results of this study are supported by previous research conducted by Cornett (2011) and Theogene (2017) who concluded that third party funds have no effect on bank risk. The results of this study are not supported by previous research conducted by Khan (2017) and Umar (2016) which concluded that the variable of third party funds or deposits has a significant effect to bank risk. However, risk management on the liability side that is too tight will make it difficult for banks to obtain funding for lending (asset side). The bank has an allowance measure for possible losses of $8 \%$ so that if it passes this provision, Bank Indonesia will give a warning (PBI/No.03/21/ PBI / 2001). So the management of liquid assets does not become the main reference in anticipating the possibility of liquidity risk.

\subsection{The Effect of Third Party Funds on Bank Risk Using Stock Return (SRV)}

The hypothesis in this study explains that third party funds have a positive and significant effect on the risk of using banks stock return (SRV). The results of hypothesis testing without using control variables or using control variables concluded that the variable from third party funds, namely, has a positive and significant effect on bank risk stock returns (SRV) because the significance values are $0.000<0.05$ and $0.001<0.05$. Risk based bank stock return (SRV) is a market based risk measurement by measuring the rate of return on shares. The higher the deviation rate of stock returns, the more risk it is to its market value. Management of third party funds that are too large will increase the bank's ability to finance credit which can generate credit income so that profits will increase. An increase in profit will attract the attention of investors so that stock prices tend to increase. An increase in stock prices will reduce the deviation level of stock returns so that the value of stock returns will be higher.

The results of this study are supported by previous research conducted by Khan (2017) who concluded that the variable third party funds or deposits has an effect to bank risk. The existence of support from previous research strengthens the theory of risk based on the return on shares. The results of this study support the prospect theory predicting an increase in risk-taking 
behavior when there is a low chance of risk occurring. However, if the risk of occurrence decreases, it will have a higher effect on long-term risk for financial services such as banks. Such as a decrease in third party funds such as deposits will reduce interest costs that must be issued by banks. However, in the long term, it will have an effect on reducing bank income through credit, because of the difficulty in getting funding sources to finance the credit.

\section{CONCLUSIONS AND SUGGESTIONS}

\subsection{Conclusions}

Based to hypothesis testing conducted by the researcher, it can be concluded that the variable third party funds has no effect on bank risk using risk weighted assets (RWA). Third party funds have no impact on loans because they have been strictly regulated by bank management and Bank Indonesia. The variable of third party funds or time deposits has a negative and significant effect on bank risk by using loan loss provisions (LLP). The higher the third party funds, the bigger the credit provided and the smaller the allowance for impairment losses, which will reduce the loan loss provision (LLP). The third party fund variable has a negative and significant effect on bank risk using the $\mathrm{Z}$ Score. The greater the third-party funds from the bank, the lower the $\mathrm{Z}$ score will be due to a decrease in profit so that the level of deviation in asset returns is greater. The variable of third party funds or deposits has no effect on bank risk by using liquidity creation (LC). The variable of third party funds has a positive and significant effect to bank risk using stock returns (SRV). Management of third party funds that are too large will increase the ability of banks to finance credit which can generate credit income so that profits and share prices tend to increase.

\subsection{Suggestions}

Based on the conclusion, management and interested parties can pay attention to research suggestions. The suggestions are:

Companies should pay attention to the management of third party funds properly because it has an impact on bank risk. The management of third party funds has an effect on reducing bank risk based on allowance for impairment on asset reserves on loans, bankruptcy distance risk based on the rate of return on assets and capital. Investors should consider the concept of third party funds accepted by banks because they have the potential for bank market risks that will harm investors. A company that is able to manage third party funds to balance its risk level is a company that has a low potential level of future losses, which will benefit its investment value.

For the government, it is better to monitor third party funds at all banks because it provides an opportunity for the threat of bankruptcy or a very high bank risk. Supervision of third party funds by the government has an impact on economic stability, because the amount of third party funds that is too large increases the risk of stock returns, as a result, weak market confidence. This will disrupt the economy as a whole. For further research, it is advisable to add new variables that may affect bank risk apart from third party funds.

\section{REFERENCES}

[1] N. Tran, T. Ha, and G. Quyen, "International Journal of Economics and Financial Issues The Impact of Funding Liquidity on Risk-taking Behaviour of Vietnamese Banks: Approaching by Z-Score Measure," Int. J. Econ. Financ. Issues, vol. 8, no. 3, pp. 29-35, 2018.

[2] M. S. Khan, H. Scheule, and E. Wu, "Funding liquidity and bank risk taking," J. Bank. Financ., vol. 82, pp. 203-216, 2017, doi: 10. 1016/j. jbankfin. 2016. 09. 005

[3] N. Nurul Firdaus, S. Iswati, and A. Rizki, "Analysis the Effect of Third Party Funds, Non Performing Financing, Capital Adequacy Ratio, and Bank Indonesia Sharia Certificates toward Financing - Case Studies of Indonesia Islamic Banking Period 2010-2015," no. June 2019, pp. 201-209, 2019, doi: 10.5220/0007540102010209.

[4] H. Xia and N. Chunsom, "Third-Party Payments Impact on Commercial Banks' Non-Interest Income: Evidence from China," Int. J. Econ. Financ., vol. 10, no. 8, p. 190, 2018, doi: 10. 5539/ijef. v10n8p190.

[5] H. Theogene, T. Mulegi, and N. Hosee, "The Contribution of Financial Ratios Analysis on Effective Decision Making in Commercial Banks The Contribution Of Financial Ratios Analysis On Effective Decision Making In Commercial Banks 1 Habimana Theogene, 2 Tom Mulegi, 3 Niyompano Hosee,” Int. J. Manag. Appl. Sci., vol. 3, no. 6, pp. 2394-7926, 2017, [Online]. Available: http://iraj.in.

[6] M. M. Cornett, J. J. McNutt, P. E. Strahan, and H Tehranian, "Liquidity risk management and credit supply in the financial crisis," J. financ. econ., vol. 101, no. 2, pp. 297-312, 2011, doi: 10.1016/j.jfineco.2011.03.001.

[7] Kasmir, Dasar-Dasar Perbankan. Jakarta: PT Raja Grafindo Persada., 2015. 
[8] U. Sekaran, Metode Penelitian Untuk Bisnis Pendekatan Pengembangan Keahlian. Jakarta: Salemba Empat, 2017.

[9] Sugiyono, Statistik Untuk Penelitian. Bandung: Alfabeta, 2017.

[10] I. ghazali, Aplikasi Analisis Multivariat Dengan Program SPSS 24. Semarang: Badan Penerbit Universitas Diponegoro, 2017.

[11] R. S. Pangestuti, "the Effect of Credit and Liquidity Risk Against Systemic Risk in Four Asean Banks," JIAFE (Jurnal Ilm. Akunt. Fak. Ekon., vol. 4, no. 1, pp. 1-8, 2019, doi: 10.34204/jiafe.v4i1.1072. 